Review

\title{
Antioxidant-Induced Stress
}

\section{Cleva Villanueva ${ }^{1, *}$ and Robert D. Kross ${ }^{2}$}

1 Escuela Superior de Medicina del IPN, Posgrado e Investigacion, Plan de San Luis y Salvador Diaz Miron S/N, Colonia Casco de Santo Tomas, Mexico, DF. 11340, Mexico

2 Kross-Link Laboratories, Bellmore, NY 11710, USA; E-Mail: krosslink@aol.com

* Author to whom correspondence should be addressed; E-Mail: villanuevacleva3@ gmail.com; Tel./Fax: +55-52-5729-6000 ext 62803.

Received: 19 December 2011; in revised form: 30 January 2012 / Accepted: 13 February 2012 / Published: 16 February 2012

\begin{abstract}
Antioxidants are among the most popular health-protecting products, sold worldwide without prescription. Indeed, there are many reports showing the benefits of antioxidants but only a few questioning the possible harmful effects of these "drugs". The normal balance between antioxidants and free radicals in the body is offset when either of these forces prevails. The available evidence on the harmful effects of antioxidants is analyzed in this review. In summary, a hypothesis is presented that "antioxidant-induced stress" results when antioxidants overwhelm the body's free radicals.
\end{abstract}

Keywords: antioxidant; oxidative stress; harmful effects

\section{Introduction}

The emergence of aerobic organisms was a consequence of oxygen becoming a significant component of the earth's atmosphere. The evolution of aerobic organisms was probably the result of their gradual adaptation to oxygen. Antioxidant enzymes probably facilitated part of such adaptation, since strict anaerobes have neither superoxide dismutase (SOD) nor catalase, whereas aerotolerant anaerobes have small levels of those enzymes [1]. Aerobic organisms use oxygen to produce the chemical energy they need to survive. Metabolic pathways of aerobic organisms lead to the obligate production of reactive oxygen species (ROS) and reactive nitrogen species (RNS), which are not necessarily bad. Indeed, reactive species are actually needed as signal transduction elements in processes that are essential for life, such as cell growth, differentiation, preconditioning and cell 
death [2,3]. They also participate in functions such as phagocytosis and stress response [4]. This echoes Barry Halliwell's [5] "All aspects of aerobic life involve free radicals and antioxidants-you cannot escape them nor should you wish to".

Free radicals are molecules or atoms characterized by possessing an unpaired electron that is always seeking a counterpart to reside inside the parent home or in the home of the other electron. Free radicals can be produced during cellular processes or as a result of the interaction of free radicals, reactive species, or free radical-generating systems with other molecules [6,7]. Many of the ROS and RNS are free radicals. There are also macromolecular radicals that are formed by the effect of oxygen, drug-induced free radicals, irradiation or free radicals on such macromolecules as protein and lipids. For example, it has been demonstrated that $\gamma$-irradiated proteins produce electron paramagnetic resonance (EPR) - detectable superoxide and huydroxyl radicals, in the presence of ferrous iron, via their intermediate conversion to hydroperoxydes [6]. Such macromolecular radicals lead to cellular dysfunction and decreased cell viability [8]. In the presence of hydrogen peroxide, aminoglutethimide (xenobiotic) modified myeloperoxidase, transforming this enzyme in a macromolecular free radical; a reaction that has been suggested to have a role in the development of drug-induced agranulocytosis and has been inhibited by polyunsaturated fatty acids [7]. Generation of lipid-derived free radicals was demonstrated, by in vivo EPR, in the livers of rats treated with the carcinogen diethylnitrosamine [9]. Lipid-derived free radicals have also been demonstrated, through EPR, in culture cells incubated with ferrous iron [10]. Free-radical modified lipids [11] and lipid-derived free radicals may play an important role in the development of atherosclerosis.

According to Halliwell and Gutteridge [12] an antioxidant is "any substance that, when present at low concentrations compared to those of an oxidizable substrate, significantly delays or prevents oxidation of that substance". Just as reactive species are not necessarily bad, antioxidants are not necessarily good. Antioxidants are a kind of matchmaker midwife trying to give or receive an electron to complete the other's "pair", but by making a proper pair, antioxidants can themselves become incomplete, and behave as free radicals; i.e., reactive and looking to pair with an unpaired electron. It is known that those "reactive" antioxidants can be stabilized (recycled) by other antioxidants, which in turn become "reactive" and can be recycled in a cascade of "reactivity mitigation" (Figure 1). It is all a matter of equilibrium. It well is accepted that oxidative stress is produced when the equilibrium between reactive species and antioxidants is tilted in favor of the former. However, the equilibrium can be broken also if antioxidant levels exceed those of the reactive species. Dündar [13] proposed the term "antioxidative stress" for such disequilibrium.

Nature is certainly wise. Aerobic organisms mitigate reactive species not only with antioxidant molecules that donate or receive electrons but also through reactions catalyzed by antioxidant enzymes. Figure 2, below, illustrates the production of superoxide by pro-oxidant enzymes and the intervention of antioxidant enzymes to stabilize such free radical. 
Figure 1. A free radical is a reactive species because it has an unpaired electron. Its reactivity is mitigated by an antioxidant (A) that donates an electron and in turn is converted to a reactive species that is recycled by a second antioxidant $(\mathbf{B})$.

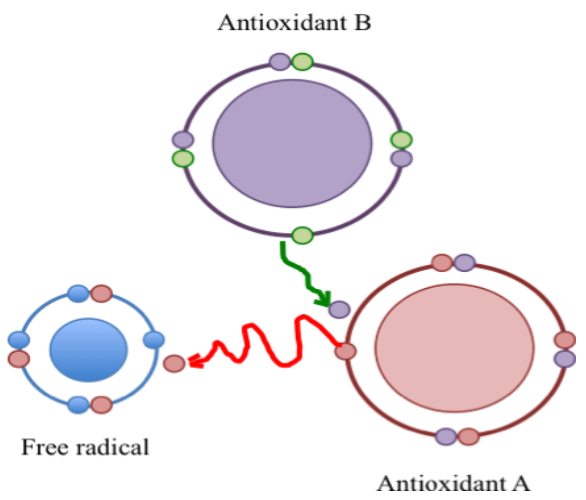

Figure 2. Superoxide radical $\left(\mathrm{O}_{2}{ }^{-}\right)$is produced from oxygen $\left(\mathrm{O}_{2}\right)$ at complex $\mathrm{I}$ and complex III of mitochondria during respiration. It can also be produced through reactions catalyzed by NADPH oxidase (NADPHox) or xanthine oxidase (XO). Superoxide dismutase (SOD) and glutathione peroxide (GPx) catalyze the conversion by superoxide into hydrogen peroxide $\left(\mathrm{H}_{2} \mathrm{O}_{2}\right.$, a reactive oxygen species). GPx requires the oxidation of glutathione (GSH) to oxidized glutathione (GSSG), which is reduced to recycle GSH through the enzyme glutathione reductase (GRx). GSH could be also used in detoxification (metabolism of the toxic $\mathrm{X}$ by conjugation with GSH) catalyzed by glutathione $\mathrm{S}$ transferase (GST). Superoxide participates in the reduction of ferric iron. Hydroxyl radical $\left(\mathrm{OH}^{*}\right)$ is formed by the interaction of $\mathrm{H}_{2} \mathrm{O}_{2}$ and ferrous ion. $\mathrm{OH}^{\cdot}$ oxidizes proteins, DNA and lipids.

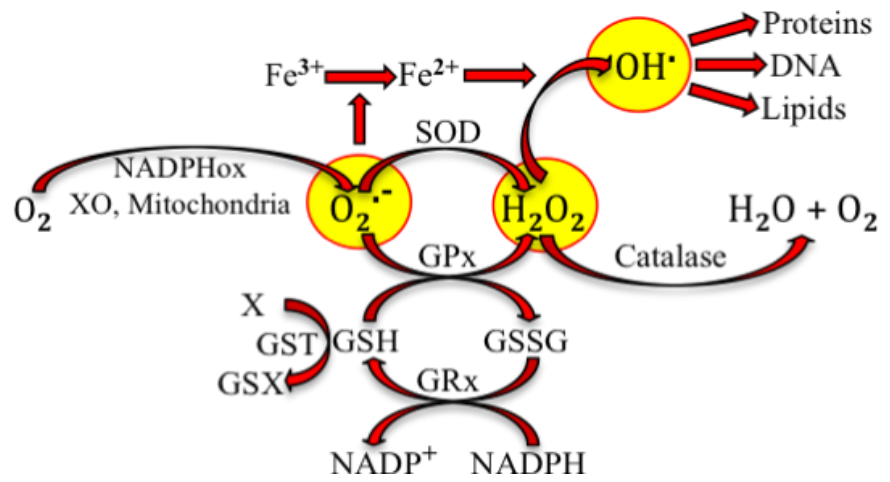

Figure 2 is only an example of the different reactions that produce reactive species, which potentially lead to oxidative stress. We have taken this very simple sequence of reactions to illustrate how changes can lead to oxidative stress and make a later parallel with the antioxidant-induced stress. Superoxide radical production can be increased if the activity of NADPHox or XO increases. Indeed, it has been postulated and partially shown, that oxidative stress in hypertension is due, at least in part, to the increase of NADPHox's activity in vascular smooth muscle cells, fibroblasts and endothelial cells $[14,15]$. Polymorphisms of the genes codifying SOD and GPx have been related to oxidative stress due to decreased activity of the enzymes and high incidence of coronary artery disease [16], ischemic stroke [17,18] and atherosclerosis [19]. Polymorphisms of GST have been associated with cardiovascular events produced in smokers [20]. 


\section{Physiological Effects of Reactive Species}

Reactive species participate in different functions and play a role as signal transduction elements in many physiological events. ROS and RNS participate in signal transduction of cytokine receptors, tyrosine receptor, serine/threonine kinases, $\mathrm{G}$ protein-coupled receptors, ion-channel linked receptors in response to angiotensin II, cytokines, glutamate, epidermal growth factor, vascular endothelial growth factor, tumor necrosis factor $\alpha$ and platelet derived growth factor [2]. Free radicals and ROS participate in the redox regulation of activator protein 1, nuclear factor $\kappa \mathrm{B}(\mathrm{NF} \kappa-\mathrm{B})$, cyclic response element-binding protein (CREB), nuclear factor E2-related factor 2 (Nrf2) and p53 ("guardian of the genome") [2,15]. Superoxide and hydrogen peroxide activate extracellular signal-related protein kinase (ERK), protein kinase B, mitogen-activated protein kinases (MAPKs) and insulin receptor kinase [15,21-23].

The effects of reactive species are dose-dependent. Incubation of Jurkat T-cells with increasing concentrations of $\mathrm{H}_{2} \mathrm{O}_{2}$ produced proliferation $(0.7 \mu \mathrm{M})$, apoptosis $(1.0-1.3 \mu \mathrm{M})$ or necrosis $(>3 \mu \mathrm{M})$ [24]. ROS participate in proteolysis into the proteasome. $\mathrm{H}_{2} \mathrm{O}_{2}$ increases proteolysis at concentrations of $20-400 \mu \mathrm{M}$, whereas it inhibits proteolysis at higher, $\mathrm{mM}$ concentrations, producing an accumulation of oxidized proteins [25]. Preconditioning is one of the areas where the dose-dependent physiological effects of reactive species are evident. Repeated or unique application of injurious stimuli, at intensities below the threshold of damage, activates endogenous mechanisms that afford protection when subsequent major injurious stimuli are applied. This phenomenon is known as preconditioning [26]. Hyperbaric oxygen [26], short ischemia [27-29], small doses of lipopolysaccharides [30], restraint stress [31], hypoxia [32], hyperthermia [32] and moderate aerobic exercise [33,34] are some of the stimuli producing preconditioning. We chose the example of exercise to explain the role of reactive species on preconditioning (see Figure 3). An excess of ROS are produced during acute or intense exercise [35,36]. It was thought that mitochondria were the primary site of superoxide production during exercise, because oxygen consumption in respiration is increased. However, it is now known that superoxide is produced mainly through NADPHox, $\mathrm{XO}$ and phospholipase $\mathrm{A}_{2}\left(\mathrm{PLA}_{2}\right)$ during intense exercise [34]. Chronic moderate exercise suppresses oxidative stress produced by acute intense exercise [34,35]. The mechanism of such adaptation seems to involve, as has been demonstrated in different studies, activation of NFא-B by ROS and the consequent expression of nitric oxide synthases and antioxidant enzymes [37-39]. Indeed, the incubation of cells with hydrogen peroxide induces the expression of antioxidant enzymes [40]. 
Figure 3. Chronic exercise increases the production of superoxide radical $\left(\mathrm{O}_{2}{ }^{-{ }^{-}}\right)$through the increase of mitochondrial respiration and activation of NADPH oxidase (NADPHox), phospholipase $\mathrm{A}_{2}\left(\mathrm{PLA}_{2}\right)$ and xanthine oxidase $(\mathrm{XO})$. The superoxide radical activates Nuclear Factor $\kappa-\mathrm{B}(\mathrm{NF \kappa}-\mathrm{B})$, which in turn produces preconditioning (increase of the endogenous antioxidant defense), characterized by the increased gene expression and activity of superoxide dismutase (SOD), glutathione peroxidase (GPx), catalase (CAT) and nitric oxide synthases (NOSs). Antioxidants interfere with the effects of chronic exercise. More details are in references [34-39,41-43].

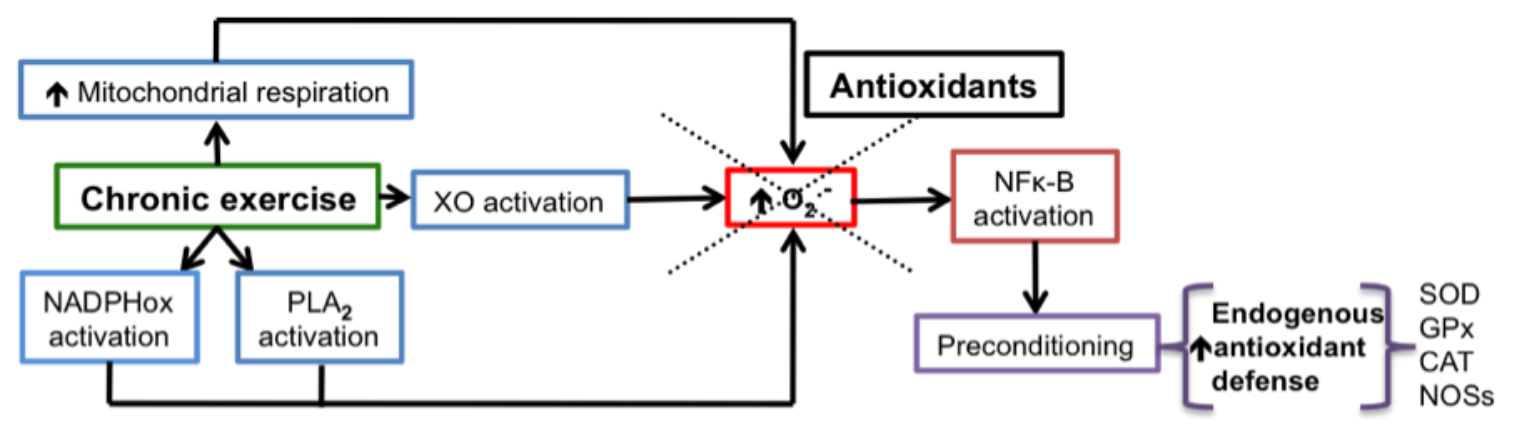

\section{Pro-Oxidant Effects of Antioxidants}

As mentioned above, antioxidants become "unstable" and "reactive" when they lose or receive electrons in the presence of reactive species (see Figure 1). In these conditions antioxidants exhibit pro-oxidant effects and can become harmful. Their redox potential (tendency to acquire electrons and thereby be reduced) could be related to the toxic effects of antioxidants. The redox potentials of some antioxidants of interest are: $0.65 \mathrm{~V}$ for $\beta$-carotene, $0.50 \mathrm{~V}$ for Vitamin $\mathrm{E}, 0.25-0.50 \mathrm{~V}$ for flavonoids, $0.25 \mathrm{~V}$ for uric acid and $0.01 \mathrm{~V}$ for Vitamin $\mathrm{C}$ [44-46]. It has been said that a network of antioxidants is necessary. Antioxidants should be interconnected in such a way that they can turn off each other's reactivity after interacting with reactive species [47]. Precisely; Damiani [48] defined a good antioxidant as one that produces a low oxidant reactivity with a low capacity to produce peroxidation.

$\alpha$-tocopherol ( $\alpha$-TC, Vitamin E) produces $\alpha$-tocopheroxyl radical $(\alpha$-TC) when it reacts with reactive species such as peroxynitrite [49] or superoxide [50]. $\alpha$-TC is then recycled to $\alpha$-TC by other antioxidants such as ascorbic acid (Vitamin C) and glutathione [48,51,52]. As soon as ascorbic acid recycles Vitamin $\mathrm{E}$, it is transformed to the ascorbyl radical, which has a lower reactivity than $\alpha$-TC [48]. $\alpha$-TC is also recycled to $\alpha$-TC by $\beta$-carotene [52,53]. Therefore, it is important that Vitamin $\mathrm{E}$ be administered with another antioxidant. It is also important to have significant levels of endogenous antioxidants to allow for the recycling of "reactive" antioxidants. Some conditions reduce endogenous antioxidants and could potentially affect the recycling of Vitamin E (or another antioxidant), leaving $\alpha$-TC' available to produce lipoperoxidation. One such condition is the reduction of ascorbic acid in smokers [48,52]. Ascorbic acid also recycles oxidized glutathione (GSSG) to reduced glutathione (GSH) [51], and carotenoid radicals to carotenoids [53]. Dihydro-lipoic acid (DHLA), the reduced form of lipoic acid (an antioxidant) recycles GSH from GSSG and the ascorbic ascorbyl radical [54]. 
The pro-oxidant or antioxidant effects of some antioxidants depend on their concentration. For example lipoic acid and DHLA inhibit nitro-tyrosine formation by peroxynitrite at a $0.01-0.05 \mathrm{mM}$ concentration, whereas promote mitochondrial permeability transition at $0.1 \mathrm{mM}$, increase of glucose intake at $0.25 \mathrm{M}$, and stimulate calcium mitochondria release at $1 \mathrm{mM}$. $\beta$-carotene protects DNA oxidative damage at $1-3 \mu \mathrm{M}$, whereas it oxidizes DNA at $4-10 \mu \mathrm{M}$. High concentrations of $\beta$-carotene inhibit the growth of cancer cells in culture and promote their apoptosis [53].

Some antioxidants exhibit pro-oxidant activities in the presence of transition metals. Such is the case of ascorbic acid that is transformed into an ascorbyl radical [55] and hydroxycinnamic acid whose phenolic groups are transformed into phenoxy reactive groups [56]. Retinal and carotenoid radical are produced by the oxidative cleavage of $\beta$-carotene in the presence of oxygen and ferrous ion $[57,58]$. Oxidative cleavage of $\beta$-carotene is also produced by many other oxidative stimuli: ultraviolet light (artificial and sun light), heat, free radicals, and ozone [59]. Carotenoid breakdown products (CBP) were produced in ferrets by cigarette smoke exposure. The effect was prevented by $\alpha$-TC and ascorbic acid [52].

Reactive species produced by the interaction of an antioxidant with a free radical such as ROS or RNS exhibit potentially toxic pro-oxidant effects. CBP inhibit mitochondrial respiration in the rat lung, brain and liver [59], stimulate apoptosis in neutrophils [59], oxidize DNA [60] and up-regulate advanced glycation endproducts [53].

In summary, the pro-oxidant and potential harmful effects of an antioxidant depend on (a) its concentration; (b) its redox potential; (c) the presence of other antioxidants; (d) the presence of transition metals, (e) the activity and concentrations of endogenous antioxidants. And, even though not yet demonstrated, the genetic background could also contribute to the harmful effects of antioxidants. Some of these factors are further considered in the following section.

\section{Clinical Trials with Antioxidants}

The validity of antioxidant therapy has been questioned, having been pointed out that even though several diseases have been related to oxidative stress, antioxidant therapy does not change the natural course of diseases [5,47,61-64]. Some authors have commented that antioxidant therapy has only been validated in experimental models of disease and cell culture [5,61]. However, different factors cause artifacts in cell culture (e.g., high oxygen levels compared to the $\mathrm{pO}_{2}$ of tissues in the organism, components of the cell culture media, high concentrations of antioxidants) [5,61]. In the clinical arena one of the problems is the biomarkers to evaluate oxidative stress [63]. It has been postulated that a combination of low doses of antioxidants could only be useful in patients suffering from antioxidant deficiencies [63]. It remains unknown if patients with gene polymorphisms affecting the structure and function of antioxidant enzymes could have different responses to antioxidants.

What is interesting is that when no effects or negative results of antioxidants are reported, there is often an alternate conclusion that antioxidants can be dangerous. For example: the method used to evaluate oxidative stress, treatment strategy (preventive strategy, doses, combination of antioxidants, duration), the stage of the disease, the follow up period, and number of patients [65]. Interestingly, in a recent review, Ristow and Schmeisser [66] suggest that life span could be extended by oxidative stress. A summary of clinical trials with antioxidants, as well as possible explanations are shown below. 


\subsection{Beneficial Effects of Antioxidants}

Nurses' Health Study (NHS). This was a cohort study of more than 87,000 U.S. nurses, ages 34-59, with no history of cardiovascular disease (CVD). Follow up period: 8 years. Results: Supplemental Vitamin E (at least 100 IU/day, for at least 2 years) was associated with reductions of $40 \%$ or more in the risk of coronary heart disease (CHD) [67,68].

Health Professional Follow up Study (HPFS). This was an observational study of around 40,000 U.S. male health professionals, ages 50-75, with no CHD, diabetes or hypercholesterolemia. Supplemental Vitamin E (at least $100 \mathrm{IU} /$ day, for at least 2 years) was associated with a significant reduction of CHD risk [67,69].

The "Established Populations for Epidemiologic Studies of the Elderly" program. This involved 11,178 U.S. men and women, ages 67-105. Results: There is a significant decreased risk of CHD mortality among those taking vitamin supplements [67,70].

The first National Health and Nutrition Examination Survey (NHANES I). This involved 11,348 U.S. women and men, ages 25-74. Conclusion: Vitamin C intake was inversely associated with all causes of mortality and CVD in men, but not in women [71].

Scottish Heart Health study. This involved 3833 women and 4036 men, ages 40-59, with no heart disease at the beginning of the study. Vitamin $\mathrm{C}$ and $\beta$-carotene intake were associated with reduced CHD, only in men [71,72].

In a recent meta-analysis Myung et al. [73] evaluated 22 case-control reports (from 274 articles), including 10,073 patients with a cervical neoplasm risk. They found preventive effects of Vitamins $B_{\mathbf{1 2}}$, $\mathrm{C}, \mathrm{E}$ and $\beta$-carotene on cervical neoplasms.

Alpha tocopherol, Beta carotene cancer prevention study (ATBC). This involved 27,111 Finnish male smokers, ages 50-69. Follow up: 16-19.4 years. Results: A higher $\alpha$ TC intake was associated with a lower pancreatic [74] and prostate [75] cancer risk. In the same study high flavonoid intake was also related to lower pancreatic cancer risk [76].

\subsection{Antioxidants Do not Change the Evolution of Diseases Related to Oxidative Stress}

20,536 patients with hypertension at high cardiovascular risk were followed for five years. Treatment with ascorbic acid, Vitamin $\mathrm{E}$ and $\beta$-carotene neither reduced blood pressure nor changed mortality or morbidity [14,77].

Rotterdam study. This involved 4,802 Dutch men and women, ages 55-95, with no history of myocardial infarction (MI). Follow up: After 4 years, no association was observed between Vitamin $\mathrm{E}$ intake and the risk of MI [71,78].

Scottish Heart Health Study (see above). No protection was associated with Vitamin E. Vitamins C, $\mathrm{E}$ and $\beta$-carotene had no effect on all-cause mortality [71].

Heart Protection Study. This included 20,536 men and women with CHD or diabetes, ages 40-80. Follow up: After 5 years, the intake of Vitamin E $(600 \mathrm{mg} /$ day $)$, Vitamin C (250 mg/day) and $\beta$-carotene (20 mg/day) had no effect [71].

Primary Prevention Project. This program involved 4,495 men and women, with an average age of 64 and at least one risk factor for CHD, who took a low dose of aspirin (100 mg/day) and Vitamin E 
(300 mg/day). The study was stopped early because other trials had demonstrated protection with aspirin. Vitamin E had no effect [71].

Heart Outcomes Prevention Evaluation Study (HOPES). This included 2545 women and 6999 men, $\geq 55$, with CHD or diabetes and one risk factor for atherosclerosis. They received Vitamin $\mathrm{E}$ (400 IU/day) or a placebo, angiotensin-converting enzyme inhibitor or a placebo. A follow up after 4.5 years indicated that Vitamin E had no effect [71,79].

Gruppo Italiano per lo Studio della Sopravvivenza nell'Infarto Miocardico (GISSI). This included 11,324 Italian men and women who had survived a myocardial infarction within the 3 previous months. They received Omega-3 oils ( $1 \mathrm{~g} /$ day) and/or Vitamin $\mathrm{E}$ or no treatment. A follow up after 3-5 years showed that Vitamin E had no effect $[71,80]$.

Rytter et al. [81] studied 40 patients with type 2 diabetes, who were randomly assigned to one of two groups, one treated with antioxidants extracted from fruits, berries and vegetables (tocopherols, carotenoids and ascorbate), and the other treated with placebo. The authors found that 12 weeks of treatment did not change the metabolic profile, neither oxidative nor inflammatory biomarkers, even though antioxidant systemic levels had increased. Recently, Suksomboon et al. [82] analyzed 9 trials including 418 type 2 diabetic patients who were treated with Vitamin $\mathrm{E}$ for 8 weeks. They found that Vitamin E did not improve glycemic control unless the patients began their treatment under bad metabolic control and with a Vitamin E deficiency.

Arain et al. [83] analyzed four clinical trials to evaluate the effects of Vitamin E on colorectal cancer. The trials included 94,069 patients (47,029 received Vitamin E) and had a follow up period of 4 years. The authors concluded that Vitamin $\mathrm{E}$ had no effect on colorectal cancer.

\subsection{Harmful Effects of Antioxidants}

We summarize here some of the published studies that show the harmful effects of antioxidant supplements in humans.

In a study made in Australia, 69 hypertensive patients with an ambulatory systolic pressure of $>125 \mathrm{mmHg}$ received treatment with Vitamin C (500 mg/day) and grape seed polyphenols (1000 mg/day) for 6 weeks. At the end of the treatment their systolic and diastolic pressures increased and there were no changes in their endothelium dependent vasodilation or oxidative stress biomarkers [84]. HDL Atherosclerosis Treatment Study (HATS). 160 men $(<70)$ and women $(<63)$, with low HDL and triglycerides $<400 \mathrm{mg} / \mathrm{dL}$. Patients were assigned to one of 4 groups: Simvastatin + niacin with or without Vitamin E (800 IU/day), Vitamin C (1000 mg/day), $\beta$ carotene $(25 \mathrm{mg} /$ day) and selenium (100 $\mu \mathrm{g} /$ day); Antioxidants or placebo. A follow up after 3 years showed that antioxidant treatment blunted HDL elevation produced by simvastatin + niacin [71,85].

The Prostate, Lung, Colorectal and Ovarian cancer Screening Trial (PLCO) was a prospective study of 25,400 postmenopausal U.S. women, ages 55-74, who were followed for 10 years. The results showed that the risk of breast cancer increased significantly (by 20\%) in women who had a folic acid supplement ( $\geq 400 \mu \mathrm{g} /$ day) whereas food folate intake was not associated with an increased risk [86]. Beta carotene and Retinal Efficacy Trial (CARET). This involved 18,314 U.S. women and men on $\beta$ carotene (30 mg/day) and Vitamin A (25,000 IU/day) or a placebo. The study had to be stopped two years prematurely because Vitamin-treatment was associated with a $28 \%$ greater incidence of lung 
cancer and 17\% more deaths than placebo treatment [71,87]. Alpha Tocopherol Beta Carotene Cancer Prevention Study (ATBC). This covered 29,133 male smokers, ages 50-69, taking $\alpha$-TC (50 mg/day) and/or $\beta$-carotene (30 mg/day). There was an $8 \%$ greater mortality in those men taking the supplements than the men treated with the placebo [71,88,89]. Bjelakovic et al. [90] published a meta-analysis of antioxidant supplements for the prevention of gastrointestinal cancer. They selected 7 high quality randomized trials (of the 14 trials examined), including 131,727 patients. They found that antioxidants significantly increased overall mortality and did not prevent gastrointestinal cancer. Myung et al. [91] analyzed 31 of 3,327 articles searched, including 22 trials with 161,045 patients (88,610 treated with antioxidants). The authors concluded that antioxidants had no preventive effects on cancer. However, when they evaluated a subgroup of four controlled trials they found that patients receiving antioxidants had a significant increase in bladder cancer.

Antioxidants Vitamin C $(12.5 \mathrm{mg} / \mathrm{Kg})$ and $\mathrm{N}$-acetylcysteine $(10 \mathrm{mg} / \mathrm{Kg})$ significantly increased the oxidative stress produced by acute exercise in healthy subjects. The effect was attributed to the conversion of ascorbic acid into the ascorbyl radical by reactive species generated during exercise [41]. Ristow et al. studied insulin sensitivity, transcriptional regulators of insulin sensitivity and gene expression of SODs, GPx and catalase in 19 trained and 20 untrained healthy young men who were treated with Vitamin E (400 IU/day) + Vitamin C (1000 mg/day) or placebo, and were trained for four weeks. They found that exercise increased insulin sensitivity as well as the gene expression of insulin sensitivity transcriptional regulators and antioxidant enzymes. The effects of exercise were blocked by antioxidant supplements [42]. Recently, Peternelj and Combes [43] evaluated 23 studies that reported negative effects of antioxidant supplements on the beneficial effects produced by chronic exercise. They found that antioxidants interfere with vasodilation and increased insulin signaling produced by exercise.

Recently, the Iowa Women's Health Study results were published [92]. The study included 38,772 women, who were older than 60 in 1986. Vitamin and mineral supplement intake was self-reported at different periods. The authors concluded that dietary Vitamin and mineral supplements may be associated with increased mortality, with the effect being worse when the supplements were accompanied by an iron supplement.

Table 1. Clinical trials with antioxidants.

\begin{tabular}{ccccccc}
\hline \multicolumn{7}{c}{ Studies reporting beneficial effects of antioxidants } \\
\hline Study & $\boldsymbol{N}$ & Age (years) & $\begin{array}{c}\text { Follow up } \\
\text { period }\end{array}$ & Antioxidant & Main Outcome & References \\
\hline $\begin{array}{c}\text { Nurses' Health } \\
\text { Study (NHS) } \\
\text { Health Professional } \\
\text { Follow up Study } \\
\text { (HPFS) }\end{array}$ & 87,245 & $34-59$ & 8 years & Vitamin E & $\begin{array}{c}\text { Significant reduction } \\
\text { in CHD risk }\end{array}$ & {$[67,68]$} \\
$\begin{array}{c}\text { Established } \\
\text { Populations for }\end{array}$ & 39,910 & $40-75$ & 4 years & Vitamin E & $\begin{array}{c}\text { Significant reduction } \\
\text { in CHD risk }\end{array}$ & {$[67,69]$} \\
$\begin{array}{c}\text { Epidemiological } \\
\text { Studies of the Elderly }\end{array}$ & 11,178 & $67-105$ & 6 years & $\begin{array}{c}\text { Vitamin E } \\
\text { with or } \\
\text { without other } \\
\text { Vitamins }\end{array}$ & $\begin{array}{c}\text { Vitamin E associated } \\
\text { with a significant } \\
\text { reduction CHD risk }\end{array}$ & {$[67,70]$} \\
\hline
\end{tabular}


Table 1. Cont.

\begin{tabular}{|c|c|c|c|c|c|c|}
\hline \multicolumn{7}{|c|}{ Studies reporting beneficial effects of antioxidants } \\
\hline Study & $N$ & Age (years) & $\begin{array}{c}\text { Follow up } \\
\text { period }\end{array}$ & Antioxidant & Main Outcome & References \\
\hline $\begin{array}{c}\text { First National } \\
\text { Health and Nutrition } \\
\text { Examination Survey } \\
\text { (NHANES I) }\end{array}$ & 11,348 & $25-74$ & 10 years & Vitamin C & $\begin{array}{l}\text { Inverse correlation } \\
\text { between Vitamin C } \\
\text { and all-cause CVD } \\
\text { death in men; not } \\
\text { women }\end{array}$ & [71] \\
\hline $\begin{array}{l}\text { Scottish Heart } \\
\text { Health Study }\end{array}$ & 7869 & $40-59$ & 10 years & $\begin{array}{l}\text { Vitamins C, E } \\
\text { and } \beta \text {-carotene }\end{array}$ & $\begin{array}{l}\text { Significant reduction } \\
\text { of CHD; only in men }\end{array}$ & {$[71,72]$} \\
\hline Meta-analysis & 10,073 & $18-90$ & NR & $\begin{array}{c}\text { Vitamins } \mathrm{C}, \mathrm{E} \\
\text { and } \mathrm{B}_{12} \text {, and } \\
\beta \text {-carotene }\end{array}$ & $\begin{array}{l}\text { Preventive effects on } \\
\text { cervical neoplasms }\end{array}$ & [73] \\
\hline $\begin{array}{l}\text { Alpha-Tocopherol, } \\
\text { Beta carotene } \\
\text { Cancer Prevention } \\
\text { Study (ATBC) }\end{array}$ & 27,111 & $50-69$ & $\begin{array}{c}16-19.4 \\
\text { years }\end{array}$ & $\begin{array}{c}\text { Alpha- } \\
\text { tocopherol, } \\
\beta \text {-carotene and } \\
\text { flavonoids }\end{array}$ & $\begin{array}{l}\text { Alpha-tocopherol } \\
\text { was associated with } \\
\text { reduced risk of } \\
\text { pancreatic and } \\
\text { prostate cancer. } \\
\text { Flavonoids were } \\
\text { associated with } \\
\text { decreased risk of } \\
\text { pancreatic cancer }\end{array}$ & [74-76] \\
\hline $\begin{array}{l}\text { Heart Protection } \\
\text { Study }\end{array}$ & 20,536 & $40-80$ & 5 years & $\begin{array}{l}\text { Vitamins C } \\
\text { and } E \text { and } \\
\beta \text {-carotene }\end{array}$ & $\begin{array}{c}\text { No reductions in } \\
\text { blood pressure, } \\
\text { morbidity or } \\
\text { mortality }\end{array}$ & {$[14,77]$} \\
\hline Rotterdam Study & 4802 & $55-95$ & 4 years & $\begin{array}{c}\text { Vitamins } C \\
\text { and } E \text { and } \beta \\
\text { carotene }\end{array}$ & $\begin{array}{l}\text { No effects of Vitamin } \\
\text { E on the risk of } \\
\text { myocardial infarction }\end{array}$ & {$[71,78]$} \\
\hline $\begin{array}{l}\text { Scottish Heart } \\
\text { Health Study }\end{array}$ & 7869 & $40-59$ & 10 years & $\begin{array}{l}\text { Vitamins C } \\
\text { and } E \text { and } \\
\beta \text {-carotene }\end{array}$ & $\begin{array}{c}\text { No effects on } \\
\text { all-cause mortality }\end{array}$ & {$[71,72]$} \\
\hline $\begin{array}{c}\text { Primary Prevention } \\
\text { Project }\end{array}$ & 4495 & 64 (average) & 3.6 years & $\begin{array}{c}\text { Vitamin E and } \\
\text { low-dose } \\
\text { aspirin }\end{array}$ & $\begin{array}{l}\text { Vitamin E had no } \\
\text { beneficial effect. } \\
\text { Trial terminated } \\
\text { because other studies } \\
\text { demonstrated the } \\
\text { beneficial effect of } \\
\text { aspirin on } \\
\text { cardiovascular } \\
\text { mortality }\end{array}$ & [71] \\
\hline $\begin{array}{l}\text { Heart Outcomes } \\
\text { Prevention } \\
\text { Evaluation Study } \\
\text { (HOPE) }\end{array}$ & 9544 & $>55$ & 4.5 years & Vitamin E & $\begin{array}{l}\text { No effect of } \\
\text { Vitamin E }\end{array}$ & {$[71,79]$} \\
\hline
\end{tabular}


Table 1. Cont.

\begin{tabular}{|c|c|c|c|c|c|c|}
\hline \multicolumn{7}{|c|}{ Studies reporting no effect of antioxidants } \\
\hline Study & $N$ & Age (years) & $\begin{array}{c}\text { Follow up } \\
\text { period }\end{array}$ & Antioxidant & Main Outcome & References \\
\hline $\begin{array}{l}\text { Gruppo Italiano per } \\
\text { lo Studio della } \\
\text { Supravvivenza nell' } \\
\text { Infarto Miocardico } \\
\text { (GISSI) }\end{array}$ & 11,324 & $\begin{array}{c}59.3 \\
\text { (average) }\end{array}$ & 3.5 years & $\begin{array}{l}\text { Vitamin } E \text { and } \\
\text { omega- } 3 \text { oils }\end{array}$ & $\begin{array}{l}\text { No effect of } \\
\text { Vitamin E }\end{array}$ & {$[71,80]$} \\
\hline $\begin{array}{c}\text { Study on well } \\
\text { controlled diabetic } \\
\text { patients }\end{array}$ & 40 & 61.9 & 12 weeks & $\begin{array}{l}\text { Extracts of } \\
\text { fruits and } \\
\text { vegetables }\end{array}$ & $\begin{array}{c}\text { No effect of the } \\
\text { extracts }\end{array}$ & [81] \\
\hline $\begin{array}{c}\text { Meta-analysis } \\
\text { including studies } \\
\text { performed in Type } 2 \\
\text { diabetic patients }\end{array}$ & 418 & $20-80$ & 8 weeks & Vitamin E & $\begin{array}{l}\text { No effects on } \\
\text { metabolic control }\end{array}$ & [82] \\
\hline Meta-analysis & 94,069 & $>49$ & $7-10$ years & Vitamin E & $\begin{array}{l}\text { No effect on } \\
\text { colorectal cancer }\end{array}$ & [83] \\
\hline $\begin{array}{l}\text { Randomized, double } \\
\text { blind, placebo } \\
\text { controlled study in } \\
\text { hypertensive } \\
\text { patients }\end{array}$ & 69 & 62 (average) & 6 weeks & $\begin{array}{l}\text { Vitamin C and } \\
\text { grape seed } \\
\text { polyphenols }\end{array}$ & $\begin{array}{c}\text { Increase of blood } \\
\text { pressure and no effect } \\
\text { on either endothelium } \\
\text { dependent } \\
\text { vasodilation or } \\
\text { oxidative stress }\end{array}$ & [84] \\
\hline $\begin{array}{l}\text { Randomized study } \\
\text { in patients with } \\
\text { CAD }\end{array}$ & 169 & 52 (average) & 3 years & $\begin{array}{l}\text { One statin, } \\
\text { Vitamin C, } \\
\text { vitamin } \mathrm{E}, \\
\beta \text {-carotene and } \\
\text { selenium }\end{array}$ & $\begin{array}{l}\text { Antioxidants blunted } \\
\text { the effect of statins } \\
\text { on HDL }\end{array}$ & {$[71,85]$} \\
\hline $\begin{array}{c}\text { Prostate, Lung, } \\
\text { Colorectal and } \\
\text { Ovarian Cancer } \\
\text { Screening Trial } \\
\text { (PLCO) }\end{array}$ & 25,400 & $55-74$ & 10 years & Folic acid & $\begin{array}{c}\text { Folic acid } \\
\text { supplementation } \\
\text { significantly } \\
\text { increased breast } \\
\text { cancer }\end{array}$ & [86] \\
\hline $\begin{array}{l}\text { Beta Carotene and } \\
\text { Retinal Efficacy } \\
\text { Trial (CARET) }\end{array}$ & 18,314 & 58 (average) & $\begin{array}{l}\text { Stopped } \\
\text { after } 2 \\
\text { years }\end{array}$ & $\begin{array}{c}\text { Vitamin A and } \\
\beta \text {-carotene }\end{array}$ & $\begin{array}{c}\text { Antioxidant treatment } \\
\text { was associated with an } \\
\text { increased incidence of } \\
\text { lung cancer and } \\
\text { mortality }\end{array}$ & {$[71,87]$} \\
\hline $\begin{array}{l}\text { Alpha- Tocopherol } \\
\text { Beta-Carotene } \\
\text { Cancer Prevention } \\
\text { Study (ATBC) }\end{array}$ & 29,133 & $50-69$ & 8 years & $\begin{array}{c}\alpha \text {-tocopherol, } \\
\beta \text {-carotene }\end{array}$ & $\begin{array}{l}\text { Antioxidants increased } \\
\text { the incidence and } \\
\text { mortality of lung } \\
\text { cancer }\end{array}$ & {$[88,89]$} \\
\hline
\end{tabular}


Table 1. Cont.

Studies reporting harmful effects of antioxidants

\begin{tabular}{|c|c|c|c|c|c|c|}
\hline Study & $N$ & Age (years) & $\begin{array}{c}\text { Follow up } \\
\text { period }\end{array}$ & Antioxidant & Main Outcome & References \\
\hline Meta-analysis & 131,727 & 55 (average) & $1-12$ years & $\begin{array}{l}\beta \text {-carotene, } \\
\text { Vitamin A, } \\
\text { Vitamin E, } \\
\text { selenium }\end{array}$ & $\begin{array}{l}\text { The antioxidant } \\
\text { treatment did not } \\
\text { prevent gastrointestinal } \\
\text { cancer but significantly } \\
\text { increased mortality }\end{array}$ & {$[90]$} \\
\hline Meta-analysis & 161,045 & $\begin{array}{c}58.4 \\
\text { (average) }\end{array}$ & $\begin{array}{c}5.3-5.8 \\
\text { years }\end{array}$ & $\begin{array}{l}\beta \text {-carotene, } \\
\text { Vitamin } C, \\
\text { Vitamin } E, \\
\text { selenium }\end{array}$ & $\begin{array}{c}\text { Increased risk of } \\
\text { bladder cancer in } 4 \text { of } \\
22 \text { of the trials included } \\
\text { in the analysis }\end{array}$ & [91] \\
\hline $\begin{array}{l}\text { Study in healthy } \\
\text { men }\end{array}$ & 14 & $\begin{array}{c}24.4 \\
\text { (average) }\end{array}$ & 7 days & $\begin{array}{c}\text { Vitamin C } \\
\text { and } N- \\
\text { Acetylcysteine }\end{array}$ & $\begin{array}{l}\text { Increase of oxidative } \\
\text { stress produced by } \\
\text { exercise }\end{array}$ & [41] \\
\hline $\begin{array}{l}\text { Study in healthy } \\
\text { men }\end{array}$ & 39 & $25-35$ & 4 weeks & $\begin{array}{c}\text { Vitamin } \mathrm{C} \text { and } \\
\text { Vitamin E }\end{array}$ & $\begin{array}{l}\text { Antioxidants blocked } \\
\text { the increase of } \\
\text { insulin sensitivity } \\
\text { and expression } \\
\text { produced by exercise }\end{array}$ & {$[42]$} \\
\hline Meta-analysis & $338 *$ & NR & $\begin{array}{l}1 \text { day- } \\
6 \text { weeks }\end{array}$ & $\begin{array}{c}\text { Allopurinol, } \\
\text { Coenzyme Q, } \\
\text { Vitamins } \\
\left(\mathrm{C}, \mathrm{E}, \mathrm{B}_{\mathbf{6}}, \mathrm{B}_{\mathbf{1 2}}\right) \text {, } \\
\alpha \text {-lipoic acid, } \\
\beta \text { - carotene, } \\
\text { lutein, } N \text { - } \\
\text { acetylcysteine, } \\
\text { Selenium } \\
\text { and/or Zinc }\end{array}$ & $\begin{array}{c}\text { Any of these effects } \\
\text { (compared to groups } \\
\text { treated with placebo): } \\
\downarrow \text { training induced } \\
\text { improvement in } \\
\text { physical performance, } \\
\downarrow \text { exercise-induced } \\
\text { oxidative stress } \\
\text { preconditioning, } \uparrow \\
\text { CK, } \uparrow \text { inflammatory } \\
\text { biomarkers, prevented } \\
\text { beneficial effects on } \\
\text { insulin sensitivity and } \\
\text { expression }\end{array}$ & {$[43]$} \\
\hline $\begin{array}{c}\text { Iowa Woman’s } \\
\text { Health Study }\end{array}$ & 38,772 & $>60$ & 14 years & $\begin{array}{c}\text { Dietary } \\
\text { vitamins and } \\
\text { mineral } \\
\text { supplements }\end{array}$ & $\begin{array}{c}\text { May be associated } \\
\text { with increased total } \\
\text { mortality risk }\end{array}$ & [92] \\
\hline
\end{tabular}

$\mathrm{CAD}=$ Coronary artery disease, $\mathrm{CHD}=$ Coronary heart disease, $\mathrm{CK}=$ creatine kinase, $\mathrm{CVD}=$ Cardiovascular disease, $\mathrm{HDL}=$ high density lipoproteins, $\mathrm{NR}=$ not reported. ${ }^{*}$ Includes 34 from Childs' [41] and Ristow's [66] studies.

Table 1 summarizes the results of the clinical trials described above. Some data command attention. The total number of study patients reporting beneficial antioxidant effects is 194,734 whereas those reporting no, or harmful effects is 554,083 (149,097 and 404,986, respectively). After comparing the 
trials, it can be concluded that the results probably depended on the population studied (age, gender, health conditions, ethnicity), antioxidants (type, combinations, supplements or dietary), follow-up period, and specific outcome. For instance, comparing the NHS study (beneficial effects) [68], with the Iowa Woman's Health Study (IWHS, harmful effects) [92], it is seen that, even though the number of participants (all women) is higher in the NHS study (more than double the IWHS), there are significant differences: participants in the NHS study were younger, the follow up period was shorter in the NHS study, the focus of the NHS study was vitamin E whereas the IWHS examined the effect of supplement and dietary vitamin/mineral, outcome in the NHS study was only cardiac heart disease, whereas outcome in the IWHS was mortality.

Similarly, comparing the HPFS study (beneficial effects) [69] with the ATBC study (harmful effects) [89], there are differences that may have influenced the results. The HPFS study was performed in healthy men, whereas the ATBC study was run with male smokers. The HPFS study examined the effect of Vitamin E; the ATBC study analyzed the effect of Vitamin E and $\beta$-carotene. The follow-up period was shorter in the HPFS study and the reported outcome was different: i.e., risk of CHD in the HPFS study vs. lung cancer and mortality in the ATBC study. Therefore, the main differences between the HPFS and ATBC studies are the particular conditions of the participants and the antioxidants related to the results. It is known that smoking produces oxidative stress and cancer [93,94]; and also known, as mentioned above, that an antioxidant is converted to a reactive species when it interacts with a free radical (Figure 1). A second antioxidant, by reacting with the "activated" antioxidant, can mitigate its free radical effects and recycle it as an antioxidant. These could explain the results of the ATBC study. Vitamin E alone did not produce any change, but the incidence of lung cancer and mortality increased in those participants who received Vitamin $\mathrm{E}$ and $\beta$-carotene [89]. Moreover, the CARET study, that looked for effects of Vitamin A and $\beta$-carotene in women and men who had worked with asbestos or were smokers [87] (both conditions are related to cancer), had to be stopped prematurely because of the clear correlation of increased lung cancer incidence and mortality. It can be postulated that $\beta$-carotene, in the presence of severe oxidatively damaged of DNA, could contribute to genomic changes leading to cancer. Interestingly, $\beta$-carotene is one of the antioxidants with the highest redox potential [46]. This characteristic could be related to the potential toxic effect of $\beta$-carotene in the presence of severe OS. A high redox potential could make $\beta$-carotene more capable of oxidizing molecules. Indeed, high concentrations of $\beta$-carotene itself oxidize DNA [53]. It has been postulated that smoke carcinogens alter carotenoid metabolism, contributing to the effects of DNA mutation and proliferation [95].

Another mechanism that seems to affect the final result of antioxidant supplementation is the normal responses of the organism to OS. In the first part of this review, it was mentioned that acute exercise produces OS [34-39]. Chronic exercise reduces the OS produced during acute exercise by activating NFK-B, which leads to gene expression of antioxidant enzymes, and NOSs [37-39]. The phenomenon is termed "preconditioning". It has been postulated that antioxidant supplements, by blocking free radicals and therefore the signal-transduction pathways that they activate during chronic exercise, inhibit such preconditioning [42,43] (see Figure 3). 


\section{Conclusions}

Even though antioxidants have been considered beneficial, a number of clinical trials have shown harmful effects. The most extreme results evidenced increased mortality in individuals taking antioxidant supplements. Although the mechanisms are not explained in those trials, the results suggest that disrupting the delicate balance between antioxidants and reactive species produces antioxidant-induced stress, if the antioxidants overwhelm the physiological production of reactive species.

Though these conclusions remain speculative, the best advice would be to ingest antioxidants from food sources rather than from self-prescribed supplements. The most probable way of increasing the endogenous antioxidant defense would be by practicing moderate aerobic exercise, as an every day healthy routine. Gene polymorphisms, which condition endogenous antioxidant deficiencies, would be the exception to such advice.

\section{Acknowledgments}

We are grateful to the authors that generously sent us PDF documents of their papers.

\section{References}

1. McCord, J.M.; Keele, B.B., Jr.; Fridovich, I. An enzyme-based theory of obligate anaerobiosis: The physiological function of superoxide dismutase. Proc. Natl. Acad. Sci. USA 1971, 68, 1024-1027.

2. Laranjinha, J. Oxidative Stress: From 1980's to Recent Update. In Oxidative Stress, Inflammation and Angiogenesis in the Metabolic Syndrome; Soares, R., Costa, C., Eds.; Springer Science + business Media: New York, NY, USA, 2009; pp. 21-32.

3. Gutierrez, J.; Ballinger, S.W.; Darley-Usmar, V.M.; Landar, A. Free radicals, mitochondria, and oxidized lipids: The emerging role in signal transduction in vascular cells. Circ. Res. 2006, 99, 924-932.

4. Durackova, Z. Some current insights into oxidative stress. Physiol. Res. 2010, 59, 459-469.

5. Halliwell, B. The wanderings of a free radical. Free Radic. Biol. Med. 2009, 46, 531-542.

6. Davies, M.J.; Fu, S.; Dean, R.T. Protein hydroperoxides can give rise to reactive free radicals. Biochem. J. 1995, 305, 643-649.

7. Narwaley, M.; Michail, K.; Arvadia, P.; Siraki, A.G. Drug-induced protein free radical formation is attenuated by unsaturated fatty acids by scavenging drug-derived phenyl radical metabolites. Chem. Res. Toxicol. 2011, 24, 1031-1039.

8. Rahmanto, A.S.; Morgan, P.E.; Hawkins, C.L.; Davies, M.J. Cellular effects of peptide and protein hydroperoxides. Free Radic. Biol. Med. 2010, 48, 1071-1078.

9. Yamada, K.; Yamamiya, I.; Utsumi, H. In vivo detection of free radicals induced by diethylnitrosamine in rat liver tissue. Free Radic. Biol. Med. 2006, 40, 2040-2046.

10. North, J.A.; Spector, A.A.; Buettner, G.R. Detection of lipid radicals by electron paramagnetic resonance spin trapping using intact cells enriched with polyunsaturated fatty acid. J. Biol. Chem. 1992, 267, 5743-5746. 
11. Leonarduzzi, G.; Gamba, P.; Gargiulo, S.; Biasi, F.; Poli, G. Inflammation-related gene expression by lipid oxidation-derived products in the progression of atherosclerosis. Free Radic. Biol. Med. 2011, 52, 19-34.

12. Halliwell, B.; Gutteridge, J.M. The definition and measurement of antioxidants in biological systems. Free Radic. Biol. Med. 1995, 18, 125-126.

13. Dündar, Y.; Aslan, R. Antioxidative stress. Eastern J. Med. 2000, 5, 45-47.

14. Pechanova, O.; Simko, F. Chronic antioxidant therapy fails to ameliorate hypertension: Potential mechanisms behind. J. Hypertens Suppl. 2009, 27, S32-S36.

15. Valko, M.; Leibfritz, D.; Moncol, J.; Cronin, M.T.; Mazur, M.; Telser, J. Free radicals and antioxidants in normal physiological functions and human disease. Int. J. Biochem. Cell Biol. 2007, 39, 44-84.

16. Nemoto, M.; Nishimura, R.; Sasaki, T.; Hiki, Y.; Miyashita, Y.; Nishioka, M.; Fujimoto, K.; Sakuma, T.; Ohashi, T.; Fukuda, K.; et al. Genetic association of glutathione peroxidase-1 with coronary artery calcification in type 2 diabetes: A case control study with multi-slice computed tomography. Cardiovasc. Diabetol. 2007, 6, 23:1-23:7.

17. Voetsch, B.; Jin, R.C.; Bierl, C.; Benke, K.S.; Kenet, G.; Simioni, P.; Ottaviano, F.; Damasceno, B.P.; Annichino-Bizacchi, J.M.; Handy, D.E.; et al. Promoter polymorphisms in the plasma glutathione peroxidase (gpx-3) gene: A novel risk factor for arterial ischemic stroke among young adults and children. Stroke 2007, 38, 41-49.

18. Naganuma, T.; Nakayama, T.; Sato, N.; Fu, Z.; Soma, M.; Aoi, N.; Hinohara, S.; Doba, N.; Usami, R. Association of extracellular superoxide dismutase gene with cerebral infarction in women: A haplotype-based case-control study. Hereditas 2008, 145, 283-292.

19. Samoila, O.C.; Carter, A.M.; Futers, S.T.; Otiman, G.; Anghel, A.; Tamas, L.; Seclaman, E. Polymorphic variants of extracellular superoxide dismutase gene in a romanian population with atheroma. Biochem. Genet. 2008, 46, 634-643.

20. Manfredi, S.; Federici, C.; Picano, E.; Botto, N.; Rizza, A.; Andreassi, M.G. Gstm1, gstt1 and cyp1a1 detoxification gene polymorphisms and susceptibility to smoking-related coronary artery disease: A case-only study. Mutat. Res. 2007, 621, 106-112.

21. Afanas'ev, I.B. Free radical mechanisms of aging processes under physiological conditions. Biogerontology 2005, 6, 283-290.

22. Afanas'ev, I.B. Signaling functions of free radicals superoxide \& nitric oxide under physiological \& pathological conditions. Mol. Biotechnol. 2007, 37, 2-4.

23. Liaudet, L.; Vassalli, G.; Pacher, P. Role of peroxynitrite in the redox regulation of cell signal transduction pathways. Front. Biosci. 2009, 14, 4809-4814.

24. Cadenas, E. Mitochondrial free radical production and cell signaling. Mol. Aspects Med. 2004, $25,17-26$.

25. Droge, W. Free radicals in the physiological control of cell function. Physiol. Rev. 2002, $82,47-95$.

26. Gu, G.J.; Li, Y.P.; Peng, Z.Y.; Xu, J.J.; Kang, Z.M.; Xu, W.G.; Tao, H.Y.; Ostrowski, R.P.; Zhang, J.H.; Sun, X.J. Mechanism of ischemic tolerance induced by hyperbaric oxygen preconditioning involves upregulation of hypoxia-inducible factor-1alpha and erythropoietin in rats. J. Appl. Physiol. 2008, 104, 1185-1191. 
27. Glantz, L.; Avramovich, A.; Trembovler, V.; Gurvitz, V.; Kohen, R.; Eidelman, L.A.; Shohami, E. Ischemic preconditioning increases antioxidants in the brain and peripheral organs after cerebral ischemia. Exp. Neurol. 2005, 192, 117-124.

28. Obrenovitch, T.P. Molecular physiology of preconditioning-induced brain tolerance to ischemia. Physiol. Rev. 2008, 88, 211-247.

29. Pradillo, J.M.; Romera, C.; Hurtado, O.; Cardenas, A.; Moro, M.A.; Leza, J.C.; Davalos, A.; Castillo, J.; Lorenzo, P.; Lizasoain, I. Tnfr1 upregulation mediates tolerance after brain ischemic preconditioning. J. Cereb. Blood Flow Metab. 2005, 25, 193-203.

30. Vartanian, K.B.; Stevens, S.L.; Marsh, B.J.; Williams-Karnesky, R.; Lessov, N.S.; Stenzel-Poore, M.P. Lps preconditioning redirects tlr signaling following stroke: Trif-irf3 plays a seminal role in mediating tolerance to ischemic injury. J. Neuroinflamm. 2011, 8, 140:1-140:12.

31. Kaur, R.; Jaggi, A.S.; Singh, N. Studies on effect of stress preconditioning in restrain stress-induced behavioral alterations. Yakugaku Zasshi 2010, 130, 215-221.

32. Gidday, J.M. Cerebral preconditioning and ischaemic tolerance. Nat. Rev. Neurosci. 2006, 7, 437-448.

33. Boveris, A.; Navarro, A. Systemic and mitochondrial adaptive responses to moderate exercise in rodents. Free Radic. Biol. Med. 2008, 44, 224-229.

34. Gomez-Cabrera, M.C.; Domenech, E.; Vina, J. Moderate exercise is an antioxidant: Upregulation of antioxidant genes by training. Free Radic. Biol. Med. 2008, 44, 126-131.

35. Syu, G.D.; Chen, H.I.; Jen, C.J. Severe exercise and exercise training exert opposite effects on human neutrophil apoptosis via altering the redox status. PLoS One 2011, 6, e24385.

36. Fisher-Wellman, K.; Bell, H.K.; Bloomer, R.J. Oxidative stress and antioxidant defense mechanisms linked to exercise during cardiopulmonary and metabolic disorders. Oxid. Med. Cell. Longev. 2009, 2, 43-51.

37. Lima-Cabello, E.; Cuevas, M.J.; Garatachea, N.; Baldini, M.; Almar, M.; Gonzalez-Gallego, J. Eccentric exercise induces nitric oxide synthase expression through nuclear factor-kappab modulation in rat skeletal muscle. J. Appl. Physiol. 2010, 108, 575-583.

38. George, L.; Lokhandwala, M.F.; Asghar, M. Exercise activates redox-sensitive transcription factors and restores renal d1 receptor function in old rats. Am. J. Physiol. Renal Physiol. 2009, 297, F1174-F1180.

39. Ji, L.L. Modulation of skeletal muscle antioxidant defense by exercise: Role of redox signaling. Free Radic. Biol. Med. 2008, 44, 142-152.

40. Veal, E.A.; Day, A.M.; Morgan, B.A. Hydrogen peroxide sensing and signaling. Mol. Cell 2007, 26, 1-14.

41. Childs, A.; Jacobs, C.; Kaminski, T.; Halliwell, B.; Leeuwenburgh, C. Supplementation with vitamin $\mathrm{c}$ and $\mathrm{n}$-acetyl-cysteine increases oxidative stress in humans after an acute muscle injury induced by eccentric exercise. Free Radic. Biol. Med. 2001, 31, 745-753.

42. Ristow, M.; Zarse, K.; Oberbach, A.; Kloting, N.; Birringer, M.; Kiehntopf, M.; Stumvoll, M.; Kahn, C.R.; Bluher, M. Antioxidants prevent health-promoting effects of physical exercise in humans. Proc. Natl. Acad. Sci. USA 2009, 106, 8665-8670.

43. Peternelj, T.T.; Coombes, J.S. Antioxidant supplementation during exercise training: Beneficial or detrimental? Sports Med. 2011, 41, 1043-1069. 
44. Sevanian, A.; Davies, K.J.; Hochstein, P. Serum urate as an antioxidant for ascorbic acid. Am. J. Clin. Nutr. 1991, 54, 1129S-1134S.

45. Pietta, P.G. Flavonoids as antioxidants. J. Nat. Prod. 2000, 63, 1035-1042.

46. Martin, H.D.; Ruck, C.; Schmidt, M.; Sell, S.; Beutner, S.; Mayer, B.; Walsh, R. Chemistry of carotenoid oxidation and free radical reactions. Pure Appl. Chem. 1999, 71, 2253-2262.

47. Halliwell, B. Are polyphenols antioxidants or pro-oxidants? What do we learn from cell culture and in vivo studies? Arch. Biochem. Biophys. 2008, 476, 107-112.

48. Damiani, E.; Astolfi, P.; Carloni, P.; Stipa, P.; Greci, L. Antioxidants: How They Work. In Oxidants in Biology; Valacchi, G., Davis, P.A., Eds.; Springer Science + Buisness Media: New York, NY, USA, 2008; pp. 251-266.

49. Botti, H.; Batthyany, C.; Trostchansky, A.; Radi, R.; Freeman, B.A.; Rubbo, H. Peroxynitritemediated alpha-tocopherol oxidation in low-density lipoprotein: A mechanistic approach. Free Radic. Biol. Med. 2004, 36, 152-162.

50. Maguire, J.J.; Wilson, D.S.; Packer, L. Mitochondrial electron transport-linked tocopheroxyl radical reduction. J. Biol. Chem. 1989, 264, 21462-21465.

51. Duracková, Z. Oxidants, Antioxidants and Oxidative Stress. In Mitochondrial Medicine; Gvozdjáková, A., Ed.; Springer Science + Business Media: New York, NY, USA, 2008; pp. 19-54.

52. Liu, C.; Russell, R.M.; Wang, X.D. Alpha-tocopherol and ascorbic acid decrease the production of beta-apo-carotenals and increase the formation of retinoids from beta-carotene in the lung tissues of cigarette smoke-exposed ferrets in vitro. J. Nutr. 2004, 134, 426-430.

53. Yeum, K.J.; Aldini, G.; Russell, R.M.; Krinsky, N.I. Antioxidant/pro-oxidant Actions of Carotenoids. In Carotenoids; Birkhäuser Verlag: Basel, Switzerland, 2009; Volume 5, pp. 235-268.

54. Moini, H.; Packer, L.; Saris, N.E. Antioxidant and prooxidant activities of alpha-lipoic acid and dihydrolipoic acid. Toxicol. Appl. Pharmacol. 2002, 182, 84-90.

55. Poljsak, B.; Gazdag, Z.; Jenko-Brinovec, S.; Fujs, S.; Pesti, M.; Belagyi, J.; Plesnicar, S.; Raspor, P. Pro-oxidative vs antioxidative properties of ascorbic acid in chromium(vi)-induced damage: An in vivo and in vitro approach. J. Appl. Toxicol. 2005, 25, 535-548.

56. Maurya, D.K.; Devasagayam, T.P. Antioxidant and prooxidant nature of hydroxycinnamic acid derivatives ferulic and caffeic acids. Food Chem. Toxicol. 2010, 48, 3369-3373.

57. Lakshman, M.R. Alpha and omega of carotenoid cleavage. J. Nutr. 2004, 134, 241S-245S.

58. Polyakov, N.E.; Leshina, T.V.; Konovalova, T.A.; Kispert, L.D. Carotenoids as scavengers of free radicals in a fenton reaction: Antioxidants or pro-oxidants? Free Radic. Biol. Med. 2001, 31, 398-404.

59. Siems, W.; Wiswedel, I.; Salerno, C.; Crifo, C.; Augustin, W.; Schild, L.; Langhans, C.D.; Sommerburg, O. Beta-carotene breakdown products may impair mitochondrial functions--potential side effects of high-dose beta-carotene supplementation. J. Nutr. Biochem. 2005, 16, 385-397.

60. Siems, W.; Salerno, C.; Crifo, C.; Sommerburg, O.; Wiswedel, I. Beta-carotene degradation products - formation, toxicity and prevention of toxicity. Forum Nutr. 2009, 61, 75-86.

61. Long, L.H.; Hoi, A.; Halliwell, B. Instability of, and generation of hydrogen peroxide by, phenolic compounds in cell culture media. Arch. Biochem. Biophys. 2010, 501, 162-169.

62. Halliwell, B. Biochemistry of oxidative stress. Biochem. Soc. Trans. 2007, 35, 1147-1150.

63. Halliwell, B.; Lee, C.Y. Using isoprostanes as biomarkers of oxidative stress: Some rarely considered issues. Antioxid. Redox Signal. 2010, 13, 145-156. 
64. Gutteridge, J.M.; Halliwell, B. Antioxidants: Molecules, medicines, and myths. Biochem. Biophys. Res Commun. 2010, 393, 561-564.

65. Fortes, C.; Virgili, F. Antioxidant vitamins are not "Just antioxidants": Not necessarily harmful when targeted to the right population. Biofactors 2008, 33, 177-180.

66. Ristow, M.; Schmeisser, S. Extending life span by increasing oxidative stress. Free Radic. Biol. Med. 2011, 51, 327-336.

67. Bowman, T.S.; Bassuk, S.S.; Gaziano, M. Interventional Trials of Antioxidants. In Atherosclerosis and Oxidant Stress: A New Perspective; Hotzman, J.L., Ed.; Springer: New York, NY, USA, 2007; pp. 25-50.

68. Stampfer, M.J.; Hennekens, C.H.; Manson, J.E.; Colditz, G.A.; Rosner, B.; Willett, W.C. Vitamin e consumption and the risk of coronary disease in women. N. Engl. J. Med. 1993, 328, 1444-1449.

69. Rimm, E.B.; Stampfer, M.J.; Ascherio, A.; Giovannucci, E.; Colditz, G.A.; Willett, W.C. Vitamin e consumption and the risk of coronary heart disease in men. N. Engl. J. Med. 1993, 328, 1450-1456.

70. Losonczy, K.G.; Harris, T.B.; Havlik, R.J. Vitamin e and vitamin c supplement use and risk of all-cause and coronary heart disease mortality in older persons: The established populations for epidemiologic studies of the elderly. Am. J. Clin. Nutr. 1996, 64, 190-196.

71. Hasnain, B.I.; Mooradian, A.D. Recent trials of antioxidant therapy: What should we be telling our patients? Cleve. Clin. J. Med. 2004, 71, 327-334.

72. Todd, S.; Woodward, M.; Tunstall-Pedoe, H.; Bolton-Smith, C. Dietary antioxidant vitamins and fiber in the etiology of cardiovascular disease and all-causes mortality: Results from the scottish heart health study. Am. J. Epidemiol. 1999, 150, 1073-1080.

73. Myung, S.K.; Ju, W.; Kim, S.C.; Kim, H. Vitamin or antioxidant intake (or serum level) and risk of cervical neoplasm: A meta-analysis. BJOG: Int. J. Obstet. Gynaecol. 2011, 118, 1285-1291.

74. Stolzenberg-Solomon, R.Z.; Sheffler-Collins, S.; Weinstein, S.; Garabrant, D.H.; Mannisto, S.; Taylor, P.; Virtamo, J.; Albanes, D. Vitamin e intake, alpha-tocopherol status, and pancreatic cancer in a cohort of male smokers. Am. J. Clin. Nutr. 2009, 89, 584-591.

75. Weinstein, S.J.; Wright, M.E.; Lawson, K.A.; Snyder, K.; Mannisto, S.; Taylor, P.R.; Virtamo, J.; Albanes, D. Serum and dietary vitamin e in relation to prostate cancer risk. Cancer Epidemiol. Biomark. Prev. 2007, 16, 1253-1259.

76. Bobe, G.; Weinstein, S.J.; Albanes, D.; Hirvonen, T.; Ashby, J.; Taylor, P.R.; Virtamo, J.; Stolzenberg-Solomon, R.Z. Flavonoid intake and risk of pancreatic cancer in male smokers (finland). Cancer Epidemiol. Biomark. Prev. 2008, 17, 553-562.

77. Heart Protection Study Collaborative Group. Mrc/bhf heart protection study of antioxidant vitamin supplementation in 20,536 high-risk individuals: A randomised placebo-controlled trial. Lancet 2002, 360, 23-33.

78. Klipstein-Grobusch, K.; Geleijnse, J.M.; den Breeijen, J.H.; Boeing, H.; Hofman, A.; Grobbee, D.E.; Witteman, J.C. Dietary antioxidants and risk of myocardial infarction in the elderly: The rotterdam study. Am. J. Clin. Nutr. 1999, 69, 261-266.

79. Yusuf, S.; Dagenais, G.; Pogue, J.; Bosch, J.; Sleight, P. Vitamin e supplementation and cardiovascular events in high-risk patients. The heart outcomes prevention evaluation study investigators. N. Engl. J. Med. 2000, 342, 154-160. 
80. GISSI-Prevenzione Investigators. Dietary supplementation with n-3 polyunsaturated fatty acids and vitamin e after myocardial infarction: Results of the gissi-prevenzione trial. Gruppo italiano per lo studio della sopravvivenza nell'infarto miocardico. Lancet 1999, 354, 447-455.

81. Rytter, E.; Vessby, B.; Asgard, R.; Ersson, C.; Moussavian, S.; Sjodin, A.; Abramsson-Zetterberg, L.; Moller, L.; Basu, S. Supplementation with a combination of antioxidants does not affect glycaemic control, oxidative stress or inflammation in type 2 diabetes subjects. Free Radic. Res. 2010, 44, 1445-1453.

82. Suksomboon, N.; Poolsup, N.; Sinprasert, S. Effects of vitamin e supplementation on glycaemic control in type 2 diabetes: Systematic review of randomized controlled trials. J. Clin. Pharm. Ther. 2011, 36, 53-63.

83. Arain, M.A.; Abdul Qadeer, A. Systematic review on "Vitamin e and prevention of colorectal cancer". Pak. J. Pharm. Sci. 2010, 23, 125-130.

84. Ward, N.C.; Hodgson, J.M.; Croft, K.D.; Burke, V.; Beilin, L.J.; Puddey, I.B. The combination of vitamin c and grape-seed polyphenols increases blood pressure: A randomized, double-blind, placebo-controlled trial. J. Hypertens. 2005, 23, 427-434.

85. Cheung, M.C.; Zhao, X.Q.; Chait, A.; Albers, J.J.; Brown, B.G. Antioxidant supplements block the response of hdl to simvastatin-niacin therapy in patients with coronary artery disease and low hdl. Arterioscler. Thromb. Vasc. Biol. 2001, 21, 1320-1326.

86. Kim, Y.I. Does a high folate intake increase the risk of breast cancer? Nutr. Rev. 2006, 64, 468-475.

87. Omenn, G.S.; Goodman, G.E.; Thornquist, M.D.; Balmes, J.; Cullen, M.R.; Glass, A.; Keogh, J.P.; Meyskens, F.L., Jr.; Valanis, B.; Williams, J.H., Jr.; et al. Risk factors for lung cancer and for intervention effects in caret, the beta-carotene and retinol efficacy trial. $J$. Natl. Cancer Inst. 1996, 88, 1550-1559.

88. Albanes, D.; Heinonen, O.P.; Taylor, P.R.; Virtamo, J.; Edwards, B.K.; Rautalahti, M.; Hartman, A.M.; Palmgren, J.; Freedman, L.S.; Haapakoski, J.; et al. Alpha-tocopherol and beta-carotene supplements and lung cancer incidence in the alpha-tocopherol, beta-carotene cancer prevention study: Effects of base-line characteristics and study compliance. J. Natl. Cancer Inst. 1996, 88, 1560-1570.

89. The Alpha-Tocopherol Beta Carotene Cancer Prevention Study Group. The effect of vitamin e and beta carotene on the incidence of lung cancer and other cancers in male smokers. The alpha-tocopherol, beta carotene cancer prevention study group. N. Engl. J. Med. 1994, 330, 1029-1035.

90. Bjelakovic, G.; Nikolova, D.; Simonetti, R.G.; Gluud, C. Antioxidant supplements for prevention of gastrointestinal cancers: A systematic review and meta-analysis. Lancet 2004, 364, 1219-1228.

91. Myung, S.K.; Kim, Y.; Ju, W.; Choi, H.J.; Bae, W.K. Effects of antioxidant supplements on cancer prevention: Meta-analysis of randomized controlled trials. Ann. Oncol. 2010, 21, 166-179.

92. Mursu, J.; Robien, K.; Harnack, L.J.; Park, K.; Jacobs, D.R., Jr. Dietary supplements and mortality rate in older women: The iowa women's health study. Arch. Intern. Med. 2011, 171, 1625-1633.

(C) 2012 by the authors; licensee MDPI, Basel, Switzerland. This article is an open access article distributed under the terms and conditions of the Creative Commons Attribution license (http://creativecommons.org/licenses/by/3.0/). 